\title{
Ideias que convulsionam, práticas que conservam: o repertório de ideias na passagem do Império à República
}

\author{
Ideas that convulse, practices that conserve: the repertoire of ideas in the passage of \\ the Empire to the Republic
}

\author{
Milene Ribas da Costa \\ Doutora em Ciências Sociais pela Unicamp \\ milacos@hotmail.com
}

Resumo: A prática política no Brasil, ao longo do século XIX, foi orientada por ideias que, no plano teórico, arquitetaram um modelo de Estado à semelhança de experiências internacionais. No entanto, as condições reais, desconhecidas ou propositalmente ignoradas, acabaram por distanciar ideal do real. O presente artigo percorre algumas importantes contribuições da historiografia, assim como da sociologia e da ciência políticas, para debater o trânsito contínuo de ideais liberais, seja no momento da Independência, seja na passagem à República. A combinação, às vezes conflituosa, desses ideais com outras doutrinas, como o positivismo na sua concepção ortodoxa, também será discutida. Nessa costura de ideias liberais e positivistas, ocorre a mudança de regime e a República apresenta-se como mais um marco do processo de modernização conservadora do país.

Palavras Chaves: liberalismo, positivismo, movimento republicano.
Abstract: Political practice in Brazil, throughout the 19th century, was guided by ideas that, at the theoretical level, designed a State model similar to international experiences. However, the real conditions, unknown or intentionally ignored, ended up distancing ideal from the real. This article goes through some important contributions of historiography, as well as of political sociology and science, to debate the continuous transit of liberal ideals, either at the time of Independence, or during the passage to the Republic. The sometimes conflicting combination of these ideals with other doctrines, such as positivism in its orthodox conception, will also be discussed. In this seam of liberal and positivist ideas, regime change occurs and the Republic presents itself as another milestone in the country's conservative modernization process.

Keywords: liberalism, positivism, republican movement. 


\section{Introdução}

Compreender movimentos políticos requer um duplo enfoque, de um lado, é necessário delinear importantes mudanças socioeconômicas, que trazem à tona novas necessidades e desafios, de outro, o movimento, que busca ter suas demandas atendidas, organiza sua pauta de reivindicações, estabelece suas estratégias, orienta planos de ação e manifestos a partir de um conjunto de ideias. Por certo, espera-se que as ideias acionadas estejam ajustadas ao objetivo que se pretende alcançar. A força e o sucesso dos movimentos dependem, em grande medida, da (in)capacidade da ordem vigente de dialogar, atender e processar demandas.

Nesse artigo objetivamos primeiro indicar, ainda que sucintamente, algumas importantes transformações que ocorreram, sobretudo, no Segundo Reinado e que contribuíram para sua desestabilização. Em seguida, discutimos como as ideias são acionadas, selecionadas e retrabalhadas, de modo que interesses sejam atendidos. As condições reais colocam-se como imã atraindo ideias e, à medida que aquelas mudam, novas ideias são acionadas e rearranjadas, sem descartar a combinação entre velhas e novas doutrinas.

O Movimento Republicano, que surge oficialmente em $1870^{1}$, deve ser pensado, de um lado, como esse imã que atrai os desacreditados e descontentes com a ordem imperial, do outro, aglutina interesses diferentes, de uma classe média urbana, passando por professores, estudantes e militares, até prósperos fazendeiros da região centro-sul do país. Como veremos, as diferenças se traduzem em propostas institucionais diferentes, porém, havia também semelhanças entre os descontentes: todos pertenciam à "ilha de letrados" do período.

Por fim, destacamos a importância das ideias no curso da história, ideias que dialogam com mudanças, nem sempre realizadas da forma como são planejadas, ou ainda, nem sempre concretizadas para promover grandes transformações, mas que impactam o curso da história, mesmo que seja para dar novo lustro em antigas estruturas.

\footnotetext{
${ }^{1}$ Consideramos importante destacar que nosso objetivo nesse artigo é tratar do movimento republicano do século XIX a partir de 1870, quando há institucionalização do movimento em torno de um partido político oficialmente criado.
} 
Se o caráter principal do acontecimento é poder situar-se com precisão nas coordenadas do espaço e do tempo, o mesmo não se dá com o processo ideológico. Este não surge de improviso ou por acaso, de um dia para o outro. Sua matéria-prima são ideias afetadas de valores, e ideias e valores se formam lentamente, com idas e vindas, no curso da história, na cabeça e no coração dos homens (BOSI, 1998: 25 - grifos do autor).

\section{Arena imperial: o contexto político-econômico do segundo reinado ${ }^{2}$}

A estrutura política e administrativa do Império torna-se alvo de inúmeras críticas no decorrer do Segundo Reinado (1840-1889), críticas potencializadas por transformações econômicas e sociais promovidas no período. A concentração de poderes políticos e o controle sobre o sistema de distribuição dos recursos públicos pelos dois partidos da ordem imperial (Partido Conservador e Partido Liberal) permitiam a distribuição de cargos públicos, postos de prestígio, prebendas de vários tipos, para segmentos pertencentes ou intimamente ligados aos conservadores e aos liberais.

Dentre as mudanças ocorridas ao longo do século XIX, e tendo-se em mente que a formação sociocultural dos atores políticos é elemento importante para a compreensão do conjunto de ideias em disputa, recorremos ao estudo de Roderick Barman e Jean Barman sobre a formação da "elite letrada" do período. Até os anos de 1820 e 1830, a geração que cursou direito em Coimbra, na metrópole portuguesa, integrava a elite econômica colonial e formava um bloco que, ao respirar os ares liberais europeus, envolveu-se com o processo de independência política da colônia. Esses jovens, ao retornarem, vão compor a elite política, seja no que hoje chamamos de alto escalão, seja nos blocos regionais de poder, e vão ter como desafio a consolidação da arquitetura

\footnotetext{
2 No momento em que ideias tornam-se instrumentos explícitos de luta política, é preciso retornar ao passado e buscar nele debates que, na aparência, apontavam para grandes mudanças, no entanto, findada a luta, observa-se a efetivação da máxima de Lampedusa, ou seja, "algo deve mudar para que tudo continue como está". O presente artigo é resultado de um duplo retorno ao passado. Primeiro, o retorno às raízes, às ideias que orientaram a independência política e, posteriormente, a mudança de regime, com a Proclamação da República em 1889. É um retorno também à minha pesquisa de mestrado, que, ao investigar a trajetória do propagandista republicano paulista Alberto Sales, percorreu o Segundo Reinado, identificando nesse período mudanças que o fragilizavam. Para uma análise mais ampla do período, abarcando, inclusive, os primeiros anos da República, consultar dissertação da autora (COSTA, 2006).
} 
institucional do país e, ao mesmo tempo, a manutenção da unidade nacional (BARMAN \& BARMAN, 1976).

O fato de terem cursado direito em Coimbra acaba contribuindo para o surgimento de uma cultura bacharelesca no país, ou seja, ao entendimento de que ser bacharel em direito era um pré-requisito para o exercício da dominação legítima - prérequisito obviamente atendido naquele momento apenas pelos filhos da elite econômica. Porém, com a Independência, cursos de direito passam a ser oferecidos em Recife e em São Paulo, facilitando e ampliando o acesso à formação superior, e, além deles, outros cursos superiores também surgem, destaque para os cursos de medicina e engenharia.

Com o tempo, as duas faculdades de direito, assim como as demais, passam a jogar no mercado um quantitativo profissional que não é mais absorvido pelas oportunidades outrora criadas pelo Estado e mais, num cenário de demanda aquecida, a oferta passa a ser mais bem controlada pela elite política tradicional, agora envolvida com a manutenção do status quo imperial e dividida nos dois partidos do establishment.

Além disso, e conforme nos mostram os autores, a geração formada em Coimbra possuía, desde os bancos da escola, uma sensibilidade com a manutenção da unidade nacional, enquanto que a geração que passa a se formar no país volta mais atenção aos problemas de sua província de origem, o que contribuirá para a simpatia com ideias republicanas, sentimento fortalecido diante do mecanismo de apadrinhamento e manutenção de status quo imperial. Em outras palavras, o curso superior em direito já não garantia mais aos jovens um lugar ao sol na política imperial ${ }^{3}$.

Enquanto os recursos concentravam-se em mãos tradicionais, transformações econômicas promovidas, em parte, pelo próprio sistema jogavam nas cidades parcelas significativas da população que se libertavam da influência direta dos grandes proprietários de terras ${ }^{4}$. A entrada, em proporções cada vez maiores, de imigrantes nas regiões mais dinâmicas alterava a composição social e reduzia a proporção de escravos nessas localidades (VIOTTI DA COSTA, 1999). À medida que a concentração

\footnotetext{
${ }^{3}$ O jornalista Quintino Bocaiúva, ao justificar sua opção pela República, esclarece que o problema do Império consistia na ausência de oportunidades aos "homens sem fortuna, desajudados de proteções eficazes, unicamente escudados na inteligência", com os quais o propagandista republicano se identificava (BOCAIÚVA apud ALONSO, 2002:108).

${ }^{4}$ A extinção do tráfico de escravos, promovida pela Lei Eusébio de Queiróz (1850), liberou capital para outras atividades econômicas e, além disso, com o crescimento da demanda de café no mercado externo, houve, num primeiro momento, migração da força de trabalho escrava do Nordeste para o Vale do Paraíba, na região centro-sul do país. Essa movimentação impactou a concentração populacional, seja no aumento da população urbana (envolvida com atividades comerciais e com a incipiente atividade industrial), seja no seu deslocamento para as regiões mais prósperas do país (VIOTTI DA COSTA, 1999).
} 
populacional se intensificava na região centro-sul do país, alterava-se a distribuição populacional, que, em contrapartida, não era acompanhada pela redistribuição de poder político, concentrado em regiões economicamente decadentes. Esse descompasso dificultava a continuidade da tradição governamental.

Assim, a "modernização conservadora" promovida pelo Gabinete Conservador de Rio Branco (1871-1875), ensejou a convivência de dois mundos: o primeiro ligado à ordem tradicional, cujos integrantes resistiriam à sua superação; o segundo ligado a uma nova estrutura econômica e social, cujos integrantes estavam apartados do sistema político, mas dele queriam fazer parte.

Ainda que não fossem essas as intenções das modernizações promovidas pelo Gabinete Rio Branco, elas contribuíram, em grande medida, para que passasse a existir dentro da ordem imperial elites descobertas das vantagens usufruídas pelos grupos tradicionais - destaque para classes urbanas escolarizadas, sobretudo no Rio de Janeiro, e para os cafeicultores do Oeste Paulista, que empregavam mão de obra livre na lavoura do café. Os excluídos, ao almejarem tais vantagens, questionariam a existência da Monarquia, enquanto os beneficiados pela ordem se agarrariam nessa existência para preservar suas vantagens (ALONSO, 2002).

Se por muito tempo as críticas ao regime foram acompanhadas de propostas reformistas, de modo que algumas mudanças fossem processadas sem ameaças ao status quo, com o Manifesto Republicano de 1870 a descrença nas reformas dá vazão a um movimento que duraria quase duas décadas e contribuiria para minar as bases da Monarquia. ${ }^{6}$

\footnotetext{
${ }^{5}$ Além de aprovar a Lei do Ventre Livre (1871), que deixava o trabalho escravo com dias contados no país, o Gabinete Conservador de Rio Branco promoveu outras importantes mudanças no período, dentre elas, destacam-se: construção de linhas telegráficas, reforma do Judiciário (destaque para ampliação do habeas-corpus), introdução do sistema métrico, construções de ferrovias, reforma do código comercial, leis trabalhistas e de naturalização de estrangeiros (com vista a incentivar a imigração) e criação de novas instituições de ensino (aspecto que ampliou o acesso ao ensino superior). Com isso o Gabinete Conservador enfraquecia a agenda liberal, ao implantar muitas propostas do programa liberal (ALONSO, 2002).

${ }^{6}$ O Manifesto Republicano foi um texto político que criou um espaço de crítica às instituições imperiais. No início do texto é definido seu espaço de atuação e seus objetivos; a sua legitimidade se funda na Constituição Política do Império. "A vocação legalista do novo partido é afirmada ao circunscrever seu campo de luta no âmbito do debate das ideias, do esclarecimento das mentes, à obra de patriotismo do resgate da sociedade brasileira ainda acorrentada ao passado colonial" (BRESCIANI, 1993: 125). Embora deixassem claro que seu objetivo não era convulsionar a ordem, a posição assumida de contestação às instituições monárquicas torna necessária a desqualificação das mesmas, incluindo-se nela os partidos existentes que, segundo os contestadores, encobriam os desmandes do regime monárquico e aceitavam as decisões políticas completamente desligadas do conhecimento do povo.
} 


\section{Ideias novas, preocupações antigas: o repertório da época ${ }^{7}$}

Em meio à conjuntura política e às turbulências econômicas e sociais, havia ideias munindo os contestadores da ordem imperial. Os interesses políticos e econômicos pautavam a recorrência a determinadas doutrinas disponíveis, em detrimento de outras. Assim como o processo que levou o Brasil à sua independência política em 1822 sofreu fortes influências do pensamento político europeu do período, o momento que precede a passagem do Império à República também é regado por ideias vindas do velho mundo e também da América do Norte.

A doutrina liberal, com sua concepção de Estado, que se fez imperativo político na Europa em fins do século XVIII e início do século XIX, modelou o pensamento político daqueles que estiveram à frente do processo de emancipação da colônia portuguesa. "Enquanto na Europa, no início do século XIX, a bandeira do liberalismo era empunhada nas revoltas da burguesia contra o poder absoluto dos reis, do lado de cá do Atlântico os mesmos princípios serviram de instrumento de luta contra o sistema colonial e a Metrópole" (GUIMARÃES \& PRADO, 2001:104).

A doutrina liberal buscava, por meio de um sistema político adequado, instrumentos capazes de assegurar as liberdades individuais e, sendo assim, tinha como principal objetivo a limitação do poder executivo frente ao poder legislativo, o que acabava por reforçar o princípio representativo - lembrando que o liberalismo, no início, aparece separado da ideia democrática, uma vez que a liberdade e representação políticas eram almejadas pela e para a classe proprietária, que não queria mais estar submetida aos desígnios de um governo tirânico (BOBBIO, 2000). Essa discussão em torno dos limites dos poderes e de garantias às liberdades individuais foi acompanhada pela elite intelectual e política brasileira, por meio de seus estudos na Europa e depois por meio de produções intelectuais que circulavam na colônia.

É nesse contexto que a independência política do país é pensada e, antes de se discutir os modelos políticos adequados e as dificuldades econômico-sociais da nova nação, os liberais brasileiros envolvem-se numa campanha antitirânica, tomando como

\footnotetext{
${ }^{7}$ Estudos historiográficos mais recentes vêm mostrando como as ideias republicanas estiveram presentes no Brasil ao longo do Primeiro Reinado e do período regencial, na condição de bandeira política defendida por liberais mais exaltados - sobre esses trabalhos ver: Basile, 2011. No entanto, nosso objetivo é tratar do Movimento Republicano a partir de 1870, momento em que há institucionalização política do movimento, por meio de um partido político oficialmente criado.
} 
base a ideia madisoniana de que a tirania consistia na acumulação de todos os poderes, legislativo, executivo e judiciário, nas mesmas mãos, seja de um, de poucos ou de muitos (BARRETO \& PAIM, 1989).

Havia nesse período precedente à Independência duas vertentes do pensamento liberal, uma radical e outra mais moderada, considerada conservadora. A primeira assim foi denominada porque defendia o liberalismo como instrumento para expressar o sentimento popular. O seu alcance não descartava a ideia de revolução; mas, devido à fraca tradição intelectual de seus melhores representantes, a vertente radical não conseguiu definir as linhas mestras de seu ideário político. A vertente moderada, que veio a predominar, buscava o novo, mas sem abrir mão do antigo (BARRETO \& PAIM, 1989).

Os principais valores da cultura política do mundo luso-brasileiro eram então definidos. O principal esforço direcionava-se no sentido de introduzir reformas - mais do que patrocinar revoluções. Aceitava-se, portanto, uma monarquia constitucional, em que uma elite de talentos era capaz de orientar a opinião pública; uma liberdade ligada à ordem; e uma igualdade regulamentada pela lei (GUIMARÃES \& PRADO, 2001:90).

A doutrina liberal aqui desenvolvida e seguida foi revolucionária e conservadora ao mesmo tempo. Revolucionária em relação à emancipação política e à destruição das instituições políticas tradicionais; e conservadora à medida que preservou a ordem interna vigente. Sendo assim, o tipo de propriedade, o tipo de economia e o tipo de mão de obra condicionaram o discurso liberal durante todo o Império. A estrutura preservada, senhorial e escravista, dificultou a implantação de uma ordem liberal nos moldes europeus; a escravidão, preservada por décadas depois da Independência, coloca-se como ponto importante para o debate ${ }^{8}$.

\footnotetext{
${ }^{8}$ Conforme nos mostra Alfredo Bosi, a trajetória do liberalismo no Brasil, ao longo do século XIX, apresenta importante divisor de águas: a queda do Gabinete Liberal de Zacarias de Góis em 1868. Até então, é possível falar de um liberalismo que carrega a marca do conservadorismo, apresentando-se, portanto, como um liberalismo moderado. Nas palavras do autor, "até meados do século, o discurso, ou o silêncio, de todos foi cúmplice do tráfico e da escravidão. O seu liberalismo, parcial e seletivo, não era incongruente: operava a filtragem dos significados compatíveis com a liberdade intra-oligárquica e descartava as conotações importunas, isto é, as exigências abstratas do liberalismo europeu que não se coadunassem com as particularidades da nova nação" (BOSI, 1998: 21). A crise política que se abre a partir de 1868, em função das ingerências do Poder Moderador, que havia destituído os liberais do poder - partido majoritário no Parlamento -, combinada com mudanças socioeconômicas e até mesmo demográficas (distribuição de mão de obra cativa entre as regiões norte e centro-sul do país) ensejam
} 
Na segunda metade do século XIX as vicissitudes do Segundo Reinado trazem novamente à tona a discussão liberal. As fraudes e limitações eleitorais, as intromissões do Poder Moderador ${ }^{9}$, a excessiva centralização político-administrativa e os privilégios da elite tradicional fortaleciam os argumentos dos questionadores daquela ordem. As ideias liberais voltariam com força à discussão do período. Entretanto, novas experiências políticas e novas doutrinas enriqueceriam a seara do debate.

As experiências francesa e norte-americana, sobretudo a última, com seu original arcabouço político-institucional, serviam como modelos a serem adaptados e seguidos pelos contestadores da ordem. Além do liberalismo, presente desde outrora, cuja implantação ainda era idealizada - até para muitos integrantes do Partido Liberal -, as ideias cientificistas também viriam a munir os propagandistas envolvidos com a construção de um novo Estado: o Estado Republicano.

O cientificismo da época chegava ao novo mundo carregado das ideias de modernidade, progresso e civilização. O método científico, as teorias evolutivas, as técnicas de observação, os estudos sobre raças, emprestados das ciências naturais por aqueles que analisavam fenômenos sociais, tornavam-se capazes de explicar a história político-social do país a partir de mecanismos tidos como irrefutáveis. Além disso, tais ideias indicavam caminhos para se engatar a sociedade na modernidade e torná-la civilizada, nos moldes europeus - sempre valorizados nesse cadinho. Tais aspectos das novas ideias funcionavam, em parte, como um verniz capaz de disfarçar o pragmatismo dos agentes que a elas recorriam.

O debate sobre os meios mais adequados para o alcance de um fim à primeira vista comum (construção da República) foi intenso. Havia entre os propagandistas algumas divergências sobre a melhor forma de alcançar e organizar o poder, de estabelecer a relação entre executivo e legislativo. Essas divergências foram alimentadas, em grande parte, pela forma como as doutrinas europeias incorporaram-se

mudanças importantes nos discursos e posicionamento dos liberais, assim, "o liberalismo de 68 já não é o liberalismo de 54. O conteúdo concreto da legitimidade, que é o coração dos valores de uma ideologia política, tinha mudado. E o motor dessa transformação fora o ideal civilizado do trabalho livre; não ainda a sua necessidade absoluta e imediata, mas o seu valor" (BOSI, 1998: 31).

${ }^{9} \mathrm{O}$ quarto poder, que na sua acepção original também era chamado de poder neutro, ao ser transportado para a realidade do Império brasileiro, sofreu adaptações que o deixaram distante da neutralidade idealizada e o tornaram alvo das críticas sobre o desvirtuamento do sistema representativo no país. Aqui, "cabia a ele, entre outros pontos, a nomeação dos senadores, a faculdade de dissolver a Câmara e convocar eleições para renová-la e o direito de sancionar, isto é, aprovar ou vetar, as decisões da Câmara ou Senado" (FAUSTO, 2000: 152). 
ao debate político. “Categorias como 'darwinismo', 'positivismo', spencerianismo', 'liberalismo' sofreram apropriações, redefinições, usos políticos” (Alonso, 2002: 31).

Entre os grupos contestadores, havia os radicais republicanos, cuja atração pelos princípios de igualdade, liberdade e participação se fazia forte. Esse grupo era composto principalmente por pequenos proprietários, profissionais liberais, jornalistas, professores e estudantes, estabelecidos na capital do Império. Ainda que suas ideias estivessem no plano da abstração, defendiam a participação popular na queda da Monarquia, aos moldes da Revolução Francesa de 1789. Embora fossem bastante agressivos em suas atuações, constituíam um grupo pequeno dentro do movimento republicano (CARVALHO, 1990).

Na província de São Paulo estava o grupo mais organizado do movimento, formado principalmente por proprietários de terras ligados à produção cafeeira. Sentindo-se sufocados pela centralização monárquica, esses agentes defendiam o modelo americano de República, alicerçado na definição individualista de "pacto social”, que minimizava a participação popular tanto no advento, quanto no governo republicano; o darwinismo social, absorvido no Brasil via Spencer, influenciava significativamente os integrantes desse movimento. "Para os republicanos de São Paulo, de Minas Gerais e do Rio Grande do Sul, três das principais províncias do Império, o federalismo era talvez o aspecto mais importante que buscavam no novo regime" (CARVALHO, 1990: 25) ${ }^{10}$. O modelo americano, em grande medida vitorioso na Constituição de 1891, atendia aos interesses, sobretudo econômicos, dos proprietários rurais dessa vertente.

Havia ainda um grupo fortemente influenciado pelas ideias positivistas e que, por seguirem fielmente as ideias de Auguste Comte, eram chamados de positivistas ortodoxos. Eles estavam principalmente na província do Rio de Janeiro, eram professores, estudantes e militares, os últimos seriam ainda responsáveis pelo desdobramento gaúcho do grupo. Defendiam, entre outros aspectos, a abolição da escravidão sem indenização, a independência entre Estado e igreja, acompanhada de

\footnotetext{
10 A centralização político-administrativa do Império limitava sobremaneira a livre iniciativa das províncias, aspecto mais duramente criticado naquelas em ascensão econômica. "As críticas atingem principalmente o presidente de província enquanto delegado do poder imperial e porta-voz dos interesses políticos do partido que o mantém. Mero instrumento político do gabinete que o nomeia, o presidente não possui interesses na região e assim não investe na prosperidade da província que governa; desconhece mesmo seus recursos naturais e as aspirações da população" (BRESCIANI, 1993: 127) - análise baseada em artigo de Campos Sales publicado em setembro de 1877 no jornal Gazeta de Campinas. Não por acaso, nessas províncias, o federalismo vai tornar-se importante bandeira política.
} 
liberdade religiosa, e a ditadura republicana, aspecto esse que os diferencia significativamente dos demais grupos propagandistas. Miguel Lemos, importante referência dessa vertente, vai defender expressamente em Manifesto de 1883 "a abolição imediata, sem indenização aos senhores, e o aproveitamento dos libertos como assalariados", esperava, ainda, que o processo ocorresse por meio de atuação do Imperador como ditador, sem que o Parlamento fosse consultado (BOSI, 1998: 33).

Os ortodoxos rejeitavam, portanto, a existência do parlamento no molde da Constituição Francesa, pois o Executivo, em sintonia com a opinião pública, é que devia determinar os rumos da República, enquanto ao Legislativo caberiam apenas questões orçamentárias. O ditador estaria comprometido com a ordem material, garantindo, ao mesmo tempo, a liberdade espiritual e moral. Os ortodoxos não integravam o Partido Republicano, opondo-se inclusive a ele, e defendiam a proclamação do Imperador como Ditador Republicano, desde que o princípio da hereditariedade fosse eliminado. Essa medida evitaria mudanças traumáticas das instituições, além de neutralizar a força da "burguesia escravista". Após a queda da Monarquia, a influência desse grupo se efetivaria não em nível federal, mas no Estado do Rio Grande do Sul (BRESCIANI, 256 1993; CARVALHO, 1990).

Se havia de um lado os ortodoxos, que aceitavam na íntegra as lições do mestre francês, havia aqueles que aceitavam a metodologia positivista, mas, ao mesmo tempo, rejeitavam suas recomendações políticas, sobretudo a ideia de ditadura republicana. Estes seriam os positivistas heterodoxos. Muitos paulistas, que se aglutinavam em torno da bandeira federalista, podem também ser considerados heterodoxos. Para eles os aspectos mais importantes da obra de Comte eram o método científico e a visão evolucionista do processo histórico social. Assim, se por um lado descartavam a dimensão política de supremacia do Executivo, por outro, recorriam aos argumentos da evolução dos Três Estados de Comte, segundo a qual a Monarquia representava um estágio ultrapassado da evolução humana, limitador do progresso social, progresso esse que só seria plenamente alcançado com a República.

À parte as diferenças entre positivistas, o Appel aux Conservateurs, que Comte publica em 1855, inspira tanto ortodoxos, quanto heterodoxos, uma vez que o autor francês defendia a necessidade de se conciliar o progresso trazido pela Revolução Francesa com a ordem necessária para se chegar à outra etapa do desenvolvimento da humanidade (CARVALHO, 1990). A ordem, como condição necessária ao processo de 
transformação político-social que conduziria ao progresso, era o aspecto mais sedutor da obra de Comte para muitos dos atores envolvidos na propaganda republicana.

Muitos daqueles que se apropriaram do método positivista, da lei dos Três Estados, ideias de ordem e de progresso, e, ao mesmo tempo, rejeitaram a ideia de ditadura republicana, combinaram conceitos do autor inglês Hebert Spencer para reforçar o veio liberal de suas propostas. Assim, suas ideias de evolução social, acompanhadas de repúdio à Monarquia e à atuação de um déspota iluminado, recheadas de propostas de modernização e amparadas pela defesa de um Estado comprometido com o laissez faire, cuja função seria proteger as liberdades individuais, dariam o tom do debate dos heterodoxos (ADDUCI, 1996).

A análise feita até aqui sobre os repertórios disponíveis no momento de convulsão política, econômica e social do Segundo Reinado não se aprofundou na composição social dos grupos contestadores, às peculiaridades de suas propostas e às formas como as teorias eram apropriadas e adaptadas àquela conjuntura, de modo que orientassem as suas respectivas ações políticas ${ }^{11}$. Entretanto, os grupos contestadores tinham em comum a condição de "marginalização política" em relação ao status quo imperial e a forma como articulavam a crítica, bem como o aspecto que escolhiam como alvo dela, estavam relacionadas ao lugar social que ocupavam e aos anseios que, a partir dele, possuíam. Lembrando que a ideia de marginalização está relacionada ao contexto da ordem imperial, pois os agentes que compunham o movimento eram todos escolarizados, ou seja, faziam parte da elite intelectual do país, mas estavam alijados das instituições políticas do Império, sob domínio de conservadores e liberais. Assim, independente das teorias escolhidas, o que estava em jogo era a construção de uma "crítica coletiva" às instituições políticas e à tradição político-intelectual do Império (ALONSO, 2002).

Se havia divergências entre positivismo e liberalismo, sobretudo no que diz respeito à forma institucional que a República deveria adotar, havia também aproximações, as quais os heterodoxos souberam trabalhar muito bem. Aproximavamse ao enxergar o Estado como agente garantidor de ordem e responsável por assegurar o livre desenvolvimento da sociedade; responsável ainda em assegurar a rapidez da

\footnotetext{
11 "Empiricamente, os membros do movimento da geração de 1870 não têm perfil homogêneo; não se prestam à operação de reduzi-los a uma única posição social. O movimento intelectual não representa exclusivamente nem a nova sociedade nem grupos decadentes. Alimenta-se de ambos" (ALONSO, 2002: 99) - para um estudo mais aprofundado sobre o movimento de contestação da ordem imperial nos anos de 1870, consultar a obra da autora.
} 
circulação de pessoas e mercadorias e a liberdade para as transações comerciais e para o fechamento de contratos. Aproximam-se, mais, ao defender a livre concorrência, como princípio da relação entre capital e trabalho, sem interferência do Estado ${ }^{12}$. Nesse sentido, tornava-se possível a construção de uma crítica à ordem imperial, seja por meio de artigos, de manifestos ou de programas, a partir de repertórios sob alguns aspectos conflitantes.

Além da situação comum de "marginalização política", de contestação à ordem imperial, de recorrência a determinados repertórios - que orientavam não apenas a produção intelectual dos agentes, mas, sobretudo a atuação política -, havia as ideias liberais estruturando as críticas voltadas às instituições imperiais. Nesse sentido, na primeira metade do século XIX, aquela preocupação em construir um governo antitirânico, nos momentos que seguiram a independência política da colônia portuguesa, voltaria, no final do mesmo século, com força ao centro do debate entre os envolvidos na construção de um novo regime.

Entretanto, em fins do Segundo Reinado, a complexidade econômica e social estimularia uma apropriação das teorias liberais que extrapolaria a preocupação centrada na limitação e independência dos poderes - até por que a experiência imperial e as críticas advindas dela colocariam essa questão como ponto pacífico no debate do período -, agora as liberdades individuais e as questões referentes à representação política ocupariam também espaço significativo na preocupação dos agentes envolvidos na construção da República. E assim o Estado Republicano aparecia como o único capaz de atender às exigências da modernidade e de estender os direitos civis e políticos àqueles que deles se sentiam excluídos.

\section{Cidadania e cidadãos: o reconhecimento dos direitos}

Falar do Movimento Republicano que se instaura a partir de 1870 é falar de um movimento composto por fazendeiros, profissionais liberais, jornalistas, estudantes de cursos superiores, professores e oficiais do Exército. Embora haja diferenças

\footnotetext{
12 "O argumento positivista cola-se à concepção liberal de Estado ao definir que este deveria cumprir a função de centro regulador das tendências dispersivas das forças sociais (...). A concordância com os preceitos liberais estende-se à concepção de que a 'livre concorrência' deve ser o princípio da relação entre o capital e o trabalho, sem que haja qualquer espécie de fiscalização por parte do Estado" (BRESCIANI, 1993: 129).
} 
significativas entre eles no tocante às posses, esses agentes tinham em comum, além da "marginalização política" em relação à ordem imperial, o pertencimento à "ilha de letrados" do período (CARVALHO, 2003).

Após a Independência Política, os letrados do início do século XIX preocuparam-se com a organização do Estado nos seus aspectos político, administrativo e jurídico. Estava em jogo a unidade política do país, que deveria se manter por meio da união das províncias e da ordem social. No final do Império os letrados, ao se envolverem num movimento cujo objetivo era a construção de um novo Estado, deparam-se com questões relacionadas à redefinição da cidadania, uma vez que agora os contestadores da ordem sentiam-se alijados dos mecanismos de participação e decisões políticas.

Como esses letrados avaliavam que o exercício pleno dos direitos civis e políticos estava inviabilizado na Monarquia, o Estado Republicano aparecia como aquele capaz de respeitar e assegurar tais direitos; de se organizar a partir dos pressupostos liberais; e de fazer valer uma verdadeira vida democrática no país. Entretanto, as expectativas referentes ao novo regime não eram homogêneas entre os grupos, havendo mesmo ideários bem distintos quanto ao papel do Estado em um Governo Republicano.

Entre os radicais republicanos, concentrados no Rio de Janeiro e defensores da participação popular na queda da Monarquia, os ideais de liberdade, igualdade e participação eram exaltados e defendidos, mas não havia uma concepção clara sobre a forma como essas plataformas seriam implantadas. Idealizavam a queda do regime aos moldes da Revolução Francesa de 1789, mas, caso tentassem uma movimentação nesse sentido, o povo, que saiu às ruas de Paris em nome da liberdade e igualdade, não se sentiria motivado para sair às ruas da capital do Império lutando pelos mesmos direitos; a dificuldade de se constituir uma República nos moldes da francesa era reconhecida por eles. Por outro lado, a solução liberal de Estado com funções e limitações bem definidas não lhes era interessante, pois não tinham recursos econômicos e sociais capazes de garantir vantagens em um sistema de competição livre. A importância do Estado estava posta. "Eram contra o regime monárquico, não contra o Estado. O Estado era o meio mais eficaz de conseguirem seus objetivos" (CARVALHO, 1998: 95).

Os positivistas ortodoxos encontrariam, em parte, uma alternativa para a problemática dos radicais republicanos. O Estado por eles idealizado era composto por um executivo forte e intervencionista, o único capaz de neutralizar os interesses de 
setores arcaicos, atendendo, ao mesmo tempo, aos interesses das novas classes. Assim, se o objetivo era o progresso na ordem, esse viria de cima, pelas mãos do próprio Estado; caberia ao governo a implementação de políticas de incorporação "ordenada" das novas classes à sociedade moderna (CARVALHO, 1987). A agitação política do terceiro estado francês aparecia como um importante momento de ruptura, de passagem para um estágio mais avançado da humanidade, entretanto, a partir dela, o objetivo seria dar sequência ao progresso dentro da ordem - conforme indicava o Appel aux Conservateurs de Auguste Comte (BRESCIANI, 1993).

Dessa forma, os ortodoxos recusariam agitações políticas, porque o terceiro estado francês já havia ingressado a humanidade na era do progresso, bastava apenas dar continuidade. O Estado tornava-se então o grande provedor das mudanças, um agente do bem comum; era o modelo de Estado paternalista que se estruturava (CARVALHO, 1990).

Se os olhos dos radicais republicanos e dos ortodoxos estavam voltados para a Europa, o mesmo não se pode dizer dos republicanos federalistas. Para eles o modelo norte-americano com a sua organização de poder colocava-se como imperativo. A definição de público como a soma dos interesses individuais justificava a defesa de seus interesses particulares e a descentralização política e administrativa, o self-government e o sistema bicameral apresentavam-se como meios para atingi-los. Argumentavam que a descentralização e a prática do self-government trariam a liberdade e a igualdade.

A ênfase na necessidade da federação - para que as liberdades fossem asseguradas e ou alcançadas - compunha uma diferença entre os contestadores integrantes da classe média urbana e os proprietários de terra, integrantes da elite econômica do país. Enquanto para os integrantes do meio urbano os principais objetivos a serem alcançados com a República eram a liberdade e a igualdade, acompanhadas para alguns da ideia de ordem e progresso, para os grandes proprietários de terra das regiões economicamente dinâmicas do país, sobretudo do Oeste Paulista, o principal objetivo era a federação, os demais aspectos apareciam como consequência dela. $\mathrm{Na}$ verdade, esses senhores preocupavam-se com a criação de um Estado capaz de assegurar seus interesses econômicos. Desse modo, a tônica do movimento republicano no Rio de Janeiro era o liberalismo, enquanto em São Paulo era o federalismo (CARVALHO: 1998).

De forma geral, os integrantes do movimento de contestação da ordem imperial reconheciam seus direitos civis e políticos e identificavam na manutenção da Monarquia 
mecanismos que os violavam. A República era a alternativa para se alcançar a cidadania plena, o tratamento igual. Mas, apesar dos preceitos liberais serem valorizados por muitos dos propagandistas, o que estava em jogo não era a construção de um Estado com funções limitadas e definidas, frente a uma sociedade livre, que se regulava por ela mesma, por meio de suas próprias iniciativas.

O modelo de Estado idealizado por cada grupo contestador tinha certamente mais atribuições e poder que o modelo clássico do Estado Liberal. Para os radicais republicanos ele era visto como provedor de oportunidades, empregos públicos e benesses; para os positivistas ortodoxos era o estimulador do progresso e o mantenedor da ordem; e para os federalistas era a estrutura capaz de garantir e proteger interesses econômicos. A nova ordem era então pensada a partir da dependência em relação ao Estado e não de autonomia perante ele. O Estado desejado, na sua idealização, já estava privatizado. Os interesses públicos e privados estavam entrelaçados e confundidos.

Nesse contexto, seria então mais correto afirmar que o movimento de reivindicação dos direitos civis e políticos, no qual se envolveram os letrados conscientemente marginalizados na ordem imperial a partir de 1870, era na verdade um movimento que reivindicava a estadania (CARVALHO, 1990). Não se tratava de uma luta pelo reconhecimento amplo de direitos e deveres dos cidadãos, com a finalidade de reduzir o poder do Estado e aumentar a autonomia do indivíduo, o que havia na verdade era o reconhecimento do excludente poder estatal do Império. O problema consistia não na existência desse poder, mas no seu alcance limitado, exclusivo à elite tradicional.

Embora tratassem de um assunto de interesse nacional, os atores envolvidos no movimento de contestação da ordem imperial, ou de defesa dela, estavam restritos às elites do Império - econômica, política e intelectual. Nesse contexto, qual era a participação dos setores mais populares da sociedade no debate? A proposta de resgatar e fortalecer os direitos civis e políticos por meio da República fazia sentido na conjuntura em que o movimento se desenvolvia? A própria ideia de República, com seus clássicos pré-requisitos, era plausível no Brasil da época?

Apesar do processo de urbanização verificado em meados do Segundo Reinado (VIOTTI DA COSTA, 1999), o peso da população urbana era pequeno, o Brasil da época era um país essencialmente rural, com quase $80 \%$ da população vivendo em áreas mais isoladas (CARVALHO: 1998). O comentário de Visconde de Uruguai sobre a macrocefalia da burocracia do Estado Imperial, que tinha uma cabeça grande estabelecida na corte e braços muito curtos que não alcançavam as municipalidades, 
denuncia a ausência do Estado pelo interior do país, onde estava a massa da população (CARVALHO, 1998). Desse modo, os habitantes da área rural, na ausência de um poder público capaz de assegurar seus direitos, estavam à mercê dos poderes privados dos senhores de terra.

A ideia de pertencimento a uma nação inexistia frente ao isolamento dos indivíduos e à ausência do Estado em boa parte das localidades. Ao isolamento social e à ausência da ideia de pertencimento a uma comunidade nacional, somavam-se os elevadíssimos índices de analfabetismo e a profunda desigualdade que se fazia notar por todas as partes - a escravidão e o latifúndio eram as primeiras e mais evidentes das desigualdades e eram, ainda, responsáveis pelo desdobramento delas em tantas outras.

Numa sociedade composta por indivíduos isolados em áreas rurais, dentro de latifúndios, majoritariamente analfabetos, sem acesso à informação e à educação, convivendo com a mão de obra escrava, qual o sentido dos direitos civis? Das liberdades individuais? Dos direitos políticos?

De um lado, na letra da lei, havia o direito à propriedade, do outro o latifúndio; havia a liberdade de ir e vir, de opinião, de escolher o trabalho, de manifestação, de organizar-se, convivendo, lado a lado, com a escravidão e com a dependência econômica do pequeno lavrador. Havia ainda a igualdade perante a lei, a lei que não conseguia entrar no latifúndio, e o direito à justiça, quando os integrantes do judiciário local eram muitas vezes indicados pelos senhores de terra. Como direito político, apesar das restrições, havia o direito ao voto, direito visto por muitos como mercadoria a ser negociada e vendida no dia da eleição; outros tinham medo de exercê-lo diante das violências cometidas nas datas dos pleitos (CARVALHO: 2001). A relação com os direitos políticos nada mais eram que desdobramentos da ausência e desconhecimento dos direitos civis. Não existia o exercício do autogoverno, o exercício de participar de uma vida política - totalmente desconhecida à massa da população.

A estrutura econômica e social, não questionada pelos propagandistas da República, impedia então a tradução e exercício dos direitos civis e políticos para a massa da população. A República, como resultado de uma ampliação da esfera pública, aspecto que a tornaria institucionalmente permeável à livre manifestação da vontade geral, sem o questionamento da ordem econômica e social, não se efetivaria no Brasil. Assim, o Estado Republicano só poderia ser como aquele temido pelo abolicionista e monarquista André Rebouças: a República dos landlords (REZENDE DE CARVALHO, 2003). 
Se a desigualdade impedia a tradução da liberdade e o sentido de direitos e deveres em relação ao Estado, como haveria preocupação com o bem público em uma sociedade onde o privado e o público apareciam confundidos? A ausência de braços estruturados do Estado pelo interior do país impedia a sua apresentação à massa da população e, assim, o poder privado, que não hesitava em dificultar esse contato, tornava-se o responsável pela interface entre Estado e Sociedade. Esse contato era então desfigurado e o direito confundido com favor e agrado, o que reforçava o laço de dependência e a necessidade de retribuição do homem livre e pobre ao senhor de terras. Nesse contexto, o voto tornava-se mecanismo de agradecimento pelos "favores" obtidos. "O votante não agia como parte de uma sociedade política, de um partido político, mas como dependente de um chefe local" (CARVALHO, 2001: 35).

Assim, se havia entre a elite conscientemente excluída o conhecimento dos direitos civis e políticos e a consciência da necessidade de assegurá-los e ampliá-los, ainda que os mecanismos para isso não descartassem uma relação bastante estreita com o Estado, havia uma ampla maioria, espalhada pelo país, completamente alheia ao assunto. A discussão sobre a importância da cidadania ficaria restrita à "ilha de letrados", assim como a concepção de bem público, entendida convenientemente por muitos como a soma dos interesses individuais - leia-se interesses dos homens de posses. Os interesses daqueles que não compunham a elite econômica, política e intelectual do período eram simplesmente desconhecidos e desconsiderados, portanto.

Dessa forma, não havia no Brasil um Terceiro Estado capaz de lutar pelos seus direitos, pelo estabelecimento da igualdade; não haveria um processo revolucionário pela conquista de direitos, que viesse a legitimar futuras manifestações para a ampliação dos mesmos; não havia virtude cívica capaz de vislumbrar um bem comum (MARSHALL, 1967). O que havia era uma profunda desigualdade inviabilizando o exercício da liberdade. A semente da República estava lançada, mas sem solo fértil para germinar. "É certo também que o sentimento republicano não estava de modo algum generalizado na consciência das elites - e, muito menos, na consciência das massas" (VIANNA, 1933: 106).

A República instaurada em 1889 estava ancorada em um arcabouço institucional, tal qual a elite econômica desejava, mas não havia o "espírito 
republicano" capaz de lhe proporcionar vida ${ }^{13}$. A desigualdade implicava falta de liberdade, que por sua vez obstruía a virtude cívica. A continuidade, sob muitos aspectos mais intensa, da privatização do público - Estado a serviço de setores minoritários e economicamente definidos, em detrimento das necessidades da ampla maioria, apartada da política, dos mecanismos de representação e incapaz de se organizar - concretizaria o temor de Rebouças. Era a República dos landlords que se instaurava. Parte da elite que idealizou a República inverteu a ordem das prioridades. Pensou que com seu advento desabrochariam aspectos que na verdade eram as premissas para a sua fecundação.

\section{Considerações finais}

Como vimos no decorrer desse artigo, ideias não brotam do nada. São lentamente cultivadas no terreno do presente e alimentadas pelas negligências daqueles que estão no poder. As modernizações superficiais podem surtir resultados imediatos, satisfazer momentaneamente, mas, na medida em que as estruturas permanecem comprometidas com uma ordem maior e excludente, o descontentamento não tarda a aparecer.

A insatisfação percorre diferentes caminhos, dialoga com diversas ideias e se corporifica em grupos e movimentos políticos que, no discurso, sustentam propostas abrangentes de transformação, e até de moralização da coisa pública, porém, a preocupação excessiva e o compromisso com a ordem, em muitos casos, parece já entregar pistas importantes do quão restritivo é o alcance do projeto transformador.

E assim práticas, outrora condenadas, já não incomodam mais, a manutenção da ordem, acompanhada de um progresso inclusivo para uma minoria e continuamente excludente para a ampla maioria da sociedade, parece colocar o país num atávico processo de modernização conservadora. Não se altera, radical e definitivamente, a

\footnotetext{
13 'Não havia república no Brasil, isto é, não havia sociedade política; não havia 'repúblicos', isto é, não havia cidadãos. Os direitos civis beneficiavam a poucos, os direitos políticos a pouquíssimos, dos direitos sociais ainda não se falava, pois a assistência social estava a cargo da Igreja e de particulares" (CARVALHO, 2001: 23-24). A participação política durante a Primeira República continuaria bastante restrita, pois, se de um lado elimina-se o critério de renda, do outro, a exclusão dos analfabetos do direito político permanecerá por muito tempo.
} 
gigantesca engrenagem da desigualdade social, apenas radicaliza-se, em dados momentos, a disputa entre ideias diferentes.

\section{Referências bibliográficas}

ADDUCI, C. C. (1996). A "Pátria Paulista": o separatismo como resposta à crise final do Império Brasileiro. São Paulo. Dissertação, mestrado, PUC-SP.

ALONSO, A. M. (2002). Ideias em Movimento: a geração de 1870 na crise do BrasilImpério. São Paulo, Ed. Paz e Terra.

BARMAN, R., \& BARMAN, J. (1976). The Role of the Law Graduate in the Political Elite of Imperial Brazil. Journal of Interamerican Studies and World Affairs, 18(4), pp. 423-450.

BARRETO, V. \& PAIM, A. (orgs.) (1989). Evolução do pensamento político brasileiro. São Paulo, EDUSP.

BASILE, M. (2011). O bom exemplo de Washington: o republicanismo no Rio de Janeiro (1830 a 1835). Varia História, Belo Horizonte, vol. 27, nº 45, pp. 17-45.

BOBBIO, N. (2000). Liberalismo e Democracia. São Paulo, Brasiliense.

BOSI, A. (1998). A escravidão entre dois liberalismos. Estudos Avançados, São Paulo, vol. 2, pp. 04-39.

BRESCIANI, M. S. M. (1993). O cidadão da República: liberalismo versus positivismo - Brasil: 1870-1900. Revista USP, São Paulo, no 17, pp. 122-135.

CARVALHO, J. M. (1987). Os bestializados: o Rio de Janeiro e a República que não foi. São Paulo, Companhia das Letras. (1990). A formação das almas: o imaginário da República do Brasil. São Paulo, Companhia das Letras.

. (1998). Pontos e bordados: escritos de história e política. Belo Horizonte. Ed. UFMG.

. (2001). Cidadania no Brasil: o longo caminho. Rio de Janeiro, Civilização Brasileira.

(2003). A construção da ordem: a elite política imperial. Rio de Janeiro, Civilização Brasileira.

CARVALHO, M. A. Rezende de (2003). Vertentes do republicanismo nos Oitocentos brasileiro. Revista USP, São Paulo, nº 59, pp. 72-85.

COSTA, E. Viotti da. (1999). Da Monarquia à República: momentos decisivos. São Paulo, Fundação Ed. da UNESP COSTA, M. R. da. (2006). A implosão da ordem: a crise final do Império e o Movimento Republicano Paulista. São Paulo. Dissertação, mestrado, FFLCH-USP.

FAUSTO, B. (2000). História do Brasil. São Paulo, EDUSP.

GUIMARÃES, L. M. P. \& PRADO, M. E. (2001). O Liberalismo no Brasil Imperial: origens, conceitos e práticas. Rio de Janeiro, Revan: UERJ.

MARSHALL, T. H (1967). Cidadania, classe social e status. Rio de Janeiro: Zahar Editores. 
VIANNA, O. (1933). O ocaso do Império. São Paulo, Melhoramentos.

Artigo recebido em 08 de fevereiro de 2020.

Aprovado em 23 de outubro de 2020.

DOI: $10.12957 /$ intellectus.2020.48332 